Vol 10, Issue 12, 2017

\title{
EFFICACY OF BOERHAAVIA DIFFUSA L. ON DISRUPTION OF GONADOTROPINS AND TESTOSTERONE IN FLUORIDE INTOXICATED MALE RATS
}

\author{
SHASHI A*, IMTIAZA KHAN \\ Department of Zoology and Environmental Sciences, Punjabi University Patiala, Punjab, India. Email: Shashiuniindia@yahoo.co.in
} Received: 11 June 2017, Revised and Accepted: 15 August 2017

\begin{abstract}
Objective: The present study explored the influence of fluoride exposure on gonadotropins and reproductive hormones.

Methods: Male Wistar albino rats weighing 100-150 g were administered with 100, 200, and 300 ppm/kg body weight of sodium fluoride daily for 20 and 40 days. The control group was given $1 \mathrm{ml}$ deionized water/kgbw/day for the same period. At the end of the experimental period, half of the animals were sacrificed and blood serum was collected and testis sample was taken concurrently. Remaining half rats were administrated with two doses (250 mg and $500 \mathrm{mg} / \mathrm{kg}$ body weight) of leaf extract of Boerhaavia diffusa L. for another 20 days. Serum level of follicle-stimulating hormone (FSH), luteinizing hormone (LH), testosterone, and intratesticular level of testosterone were evaluated.
\end{abstract}

Results: It was found that fluoride intoxication resulted in significant increase in the level of FSH (p<0.01) and LH (p<0.0001) while significant decrease in the serum $(\mathrm{p}<0.01)$ and testis $(\mathrm{p}<0.0001)$ level of testosterone. A significant $(\mathrm{p}<0.0001)$ positive correlation was found between level of serum fluoride and gonadotropins: FSH (20 days, r=0.708 and 40 days, r=0.795) and LH (20 days, r=0.779 and 40 days, $r=0.891$ ). However, there was significant $(\mathrm{p}<0.0001)$ negative correlation existed between serum fluoride and testosterone levels in serum $(20$ days, $\mathrm{r}=-0.780$ and 40 days, $\mathrm{r}=-0.862$ ) as well as testis (20 days, $\mathrm{r}=-0.915$ and 40 days, $\mathrm{r}=-0.938$ ).

Conclusion: It was found that administration of $B$. diffusa L. alleviated the adverse effects of fluoride on reproductive endocrine functions.

Keywords: Boerhaavia diffusa L., Fluoride, Follicle-stimulating hormone, Luteinizing hormone, Testosterone.

(C) 2017 The Authors. Published by Innovare Academic Sciences Pvt Ltd. This is an open access article under the CC BY license (http://creativecommons. org/licenses/by/4. 0/) DOI: http://dx.doi.org/10.22159/ajpcr.2017.v10i12.20604

\section{INTRODUCTION}

Epidemiological studies on environmental exposure to fluoride have been associated with male infertility and low birth rates of people living in endemic areas of fluorosis [1].

The adult male reproductive function is considered to be controlled by the hypothalamus-pituitary-testicular axis through a negative feedback mechanism [2]. It played a key role in maintaining the sex hormones secretion. In this system, gonadotropin-releasing hormone (GnRH) from hypothalamus controls the synthesis and the release of pituitary gland hormones, follicle-stimulating hormone (FSH), and luteinizing hormone (LH). Then, they activate FSH and LH receptors in testis regulating the development of testes, steroid biosynthesis, and spermatogenesis [3]. It has been observed in male rats that fluoride could affect hormone levels of each layer of the hypothalamushypophysis-testis axis, which then may disturb the reproductive endocrine function [4].

Recently, mounting alertness in finding natural antioxidant phytoconstituents from plants has drawn more concern. Plant materials and products are a rich repository of an array of biologically active compounds such as antioxidants and free radical scavengers. To the best of our knowledge, this is the first study concerning the effect of Boerhaavia diffusa L. against fluoride-induced reproductive toxicity.

However, fewer studies have been conducted to explore the relationship between serum fluoride and male sex hormone levels. Hence, the present study has been designed to evaluate the ameliorative role of $B$. diffusa on fluoride-induced alteration in the concentration of gonadotropins and testosterone.

\section{METHODS}

Young male Wistar rats weighing between 100 and $150 \mathrm{~g}$ were housed in polypropylene cages with stainless steel grill tops and fed with standard rat pellet diet (Hindustan Lever Limited, India) and maintained in an air conditioned animal house facility with controlled temperature $\left(22-25^{\circ} \mathrm{C}\right), 12 \mathrm{hrs}$ light/dark cycle, and humidity. The water was given ad libitum. The experiments were performed under the approval of Institutional Animal Ethics Committee, Punjabi University Patiala (Approval number 107/99/CPCSEA-2012-11).

\section{Chemical and diagnostic kits}

Sodium fluoride (NaF) (guaranteed reagent) was purchased from Merck Specialties Pvt., Ltd., India; enzyme-linked immunosorbent assay (ELISA) kits of Testosterone by Diametra, FSH and LH ELISA kits by Weldon Biotech were purchased.

\section{Experimental design}

After acclimatization to environment for 1 week, the male rats were divided randomly into 12 equal groups with six rats in each group: Control group (C1) was administered deionized water for 20 and 40 days; the rats in experimental groups received 100, 200, and $300 \mathrm{ppm} \mathrm{NaF/kg} \mathrm{bw/day,}$ for the same days by oral gavage. Rats treated with $\mathrm{NaF}$ for 40 days were post-treated with 250 and $500 \mathrm{mg} / \mathrm{kg}$ bw/day of $B$. diffusa extract for next 20 days. Positive controls were administered with 250 (C2) and 500 (C3) $\mathrm{mg} / \mathrm{kg}$ bw/day of B. diffusa leaf extract, respectively. At the end of the experimental period, rats were fasted overnight and sacrificed. Blood samples were collected from lateral tail vein.

\section{Preparation of plant extract}

The leaf extract of $B$. diffusa was prepared by the method of Narendhirakannan et al. [5]. 
Hormonal analysis

The serum level of FSH, LH, testosterone, and intratesticular testosterone level in control and fluoride-treated rats was determined using commercial test kits by following methods given in respective datasheet.

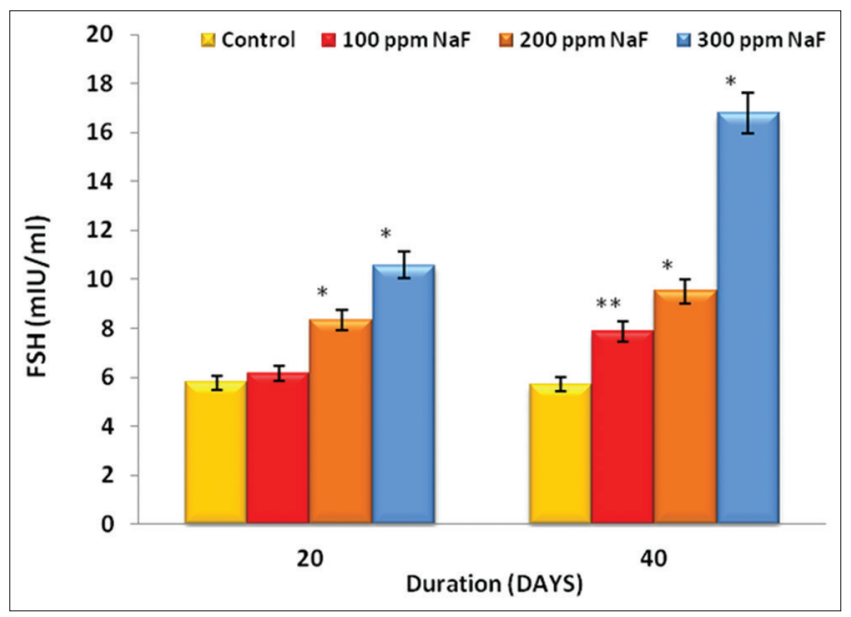

Fig. 1: Serum level of follicle-stimulating hormone in control and sodium fluoride ( $\mathrm{NaF})$-treated rats. Values are expressed as mean \pm SD. ${ }^{*} \mathbf{p}<0.0001$ and ${ }^{* *} \mathbf{p}<0.01$ NaF-treated groups compared with control

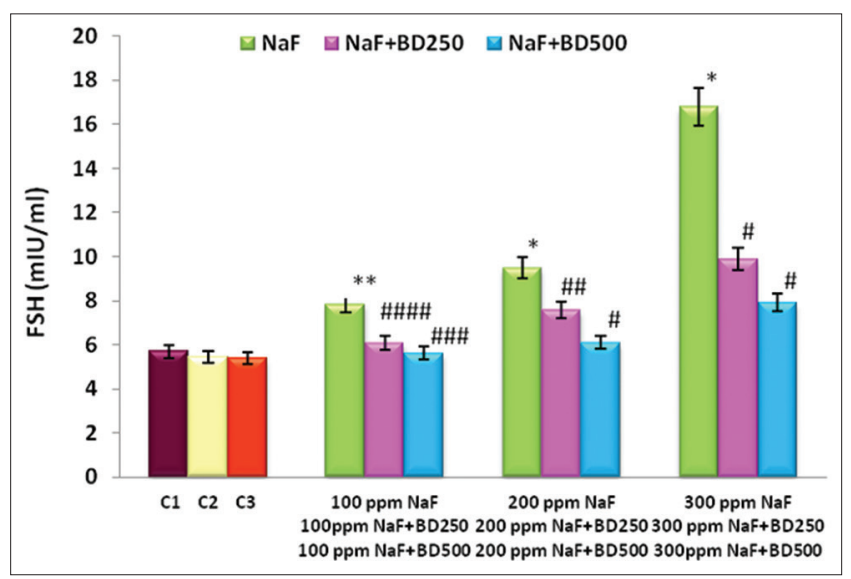

Fig. 2: Serum level of follicle-stimulating hormone in control (C1), positive controls ( $\mathrm{C} 2$ and $\mathrm{C} 3$ ), sodium fluoride ( $\mathrm{NaF}$ )-treated, and combination of $\mathrm{NaF}$ and leaf extract-treated group. Values are represented as mean \pm SD. ${ }^{*} \mathbf{p}<0.0001$ and ${ }^{* *} \mathbf{p}<0.01$ compared with control (C1). ${ }^{\#} \mathbf{p}<0.0001,{ }^{\# \#} \mathbf{p}<0.001,{ }^{\# \#} \mathbf{p}<0.01$, and ${ }^{\# \# \#} \mathbf{p}<0.05$ compared to respective NaF-treated group

\section{RESULTS}

FSH

The serum level of FSH of test rat showed significant $(\mathrm{p}<0.0001)$ increase after $20(\mathrm{~F}=44.878)$ and after 40 days $(\mathrm{F}=139.127)$ of fluoride treatment. Maximum percentage increase of $194.09 \%$ was registered in 300 ppm NaF group (Fig. 1).

Bonferroni multiple comparison test after ANOVA demonstrated a significant increase in the FSH level between and within groups after $20(95 \%, \mathrm{CI}=-3.8920$ to $-0.9015, \mathrm{p}<0.001)$ and $40(95 \%$, $\mathrm{Cl}=-10.5994$ to $-5.5869, \mathrm{p}<0.0001$ ) days of fluoride exposure.

Dunnett's t (2-sided) multiple comparison test revealed that serum FSH level was decreased significantly in all fluoridated rats post-treated with $250(95 \%, \mathrm{Cl}=-3.2976$ to $-5.7708, \mathrm{p}<0.05)$ and $500 \mathrm{mg} / \mathrm{kg}$ bw/day (95\%, $\mathrm{Cl}=-3.7456--7.7443, \mathrm{p}<0.001$ ) leaf extract of $B$. diffusa (Fig. 2).

Pearson's bivariate correlation analysis showed significant $(\mathrm{p}<0.0001)$ positive relationship between serum level of fluoride and FSH in experimental rats after $20(\mathrm{r}=0.708$; Fig. $3 \mathrm{a})$ and 40 days $(\mathrm{r}=0.795$; Fig. 3b) of fluoride intoxication.

\section{LH}

The serum level of LH of test rat showed a significant $(\mathrm{p}<0.0001)$ increase after $20(\mathrm{~F}=139.718)$ and 40 days $(\mathrm{F}=306.103)$ of fluoride treatment. More prominent (561.32\%) elevation was registered in the highest dose group (Fig. 4).

Bonferroni multiple comparison test after ANOVA depicted a significant $(p<0.0001)$ increase in the LH level between and within groups after $20(95 \%, \mathrm{CI}=-4.5567--2.4161)$ and 40 days $(95 \%, \mathrm{Cl}=-3.8338$ to $-1.1690)$ of fluoride exposure.

Dunnett's t (2-sided) multiple comparison test revealed that serum LH level was significantly $(\mathrm{p}<0.0001)$ decreased in all fluoridated rats posttreated with $250(95 \%, \mathrm{Cl}=-2.6262$ to -2.2337$)$ and $500 \mathrm{mg} / \mathrm{kg}$ bw/day ( $95 \%, \mathrm{Cl}=-3.3587$ to -4.7290 ) leaf extract of $B$. diffusa (Fig. 5).

Pearson's bivariate correlation analysis showed a significant $(\mathrm{p}<0.0001)$ positive relationship between serum level of fluoride and LH in experimental rats after 20 (r=0.779; Fig. 6a) and 40 days $(r=0.891$; Fig. 6b) of fluoride intoxication.

\section{Testosterone}

Serum

The serum level of testosterone in fluorotic rats showed a significant $(\mathrm{p}<0.0001)$ decrease after 20 days $(\mathrm{F}=15.332)$ and 40 days $(\mathrm{F}=39.368)$ as compared to control. More prominent decrease $(81.49 \%)$ was registered in group treated with 300 ppm fluoride/kg b.w./day after 40 days of fluoride intoxication (Fig. 7).
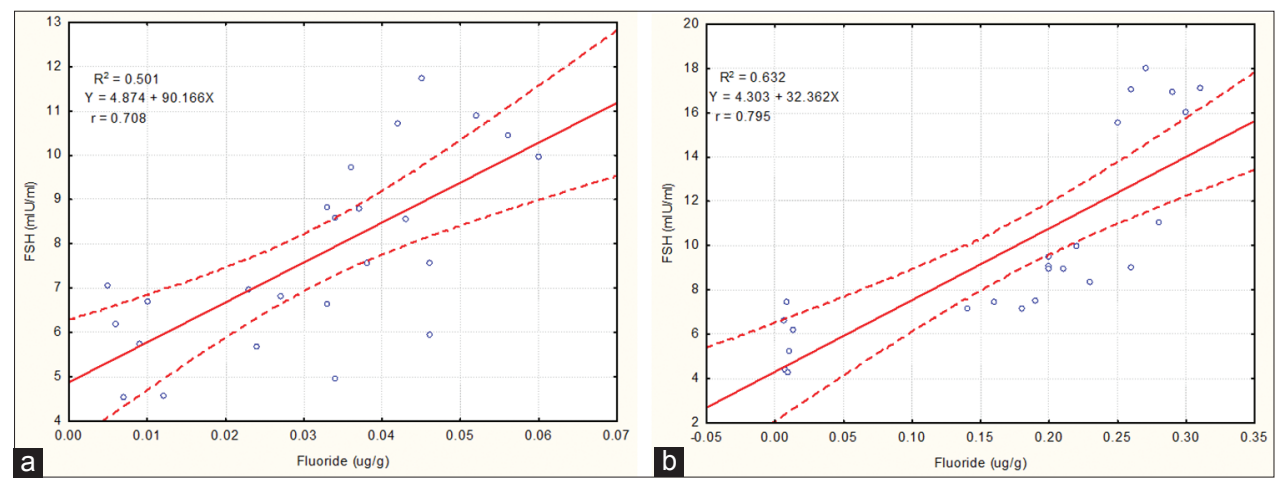

Fig. 3: Correlation and linear regression between serum level of fluoride and follicle-stimulating hormone after (a) 20 days, and (b) after 40 days of fluoride intoxication 
Bonferroni multiple comparison test after ANOVA displayed a significant $(\mathrm{p}<0.001)$ decrease in the serum testosterone between and within groups treated with fluoride for 20 (95\%, CI=0.6402 to 3.3608 , $\mathrm{p}<0.01)$ and 40 days $(95 \%, \mathrm{Cl}=0.4316$ to $3.3501, \mathrm{p}<0.05)$ of fluoride treatment.

Dunnett's $\mathrm{t}$ (2-sided) multiple comparison test revealed that serum testosterone level was significantly $(\mathrm{p}<0.001)$ increased in rats post-

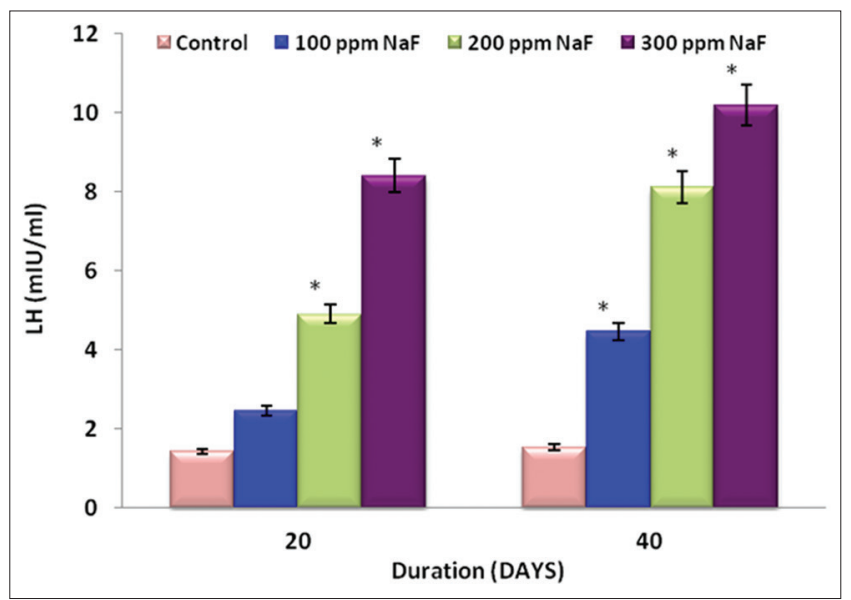

Fig. 4: Serum level of luteinizing hormone in control and sodium fluoride (NaF)-treated rats. Values are expressed as mean \pm SD.

${ }^{*} \mathbf{p}<0.0001 \mathrm{NaF}$-treated groups compared with control

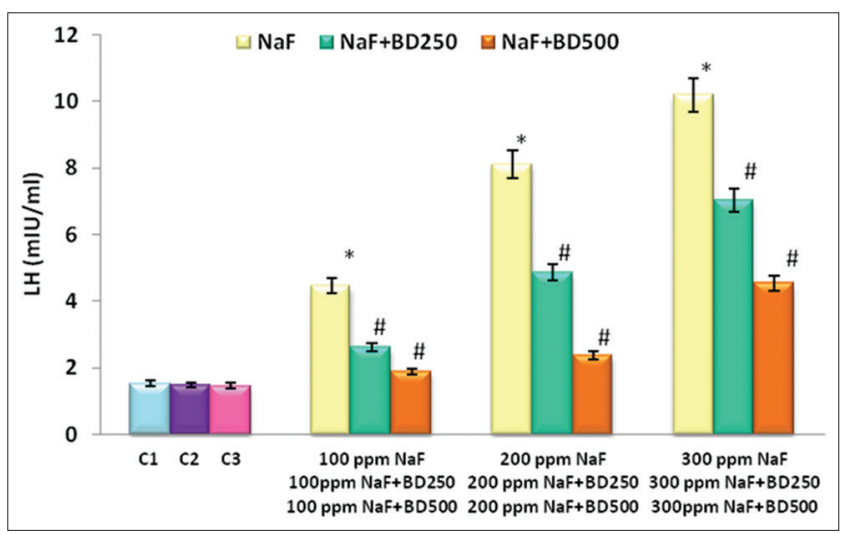

Fig. 5: Serum level of luteinizing hormone in control (C1), positive control ( $\mathrm{C} 2$ and $\mathrm{C} 3$ ), sodium fluoride ( $\mathrm{NaF}$ )-treated, and combination of $\mathrm{NaF}$ and leaf extract-treated group. Values are represented as mean \pm SD. ${ }^{*} \mathbf{p}<0.0001$ compared with control (C1). ${ }^{\#} \mathbf{p}<0.0001$ compared to respective NaF-treated group treated with 250 (95\%, $\mathrm{CI}=0.8305$ to 3.5822$)$ and $500 \mathrm{mg} / \mathrm{kg} \mathrm{bw} /$ day (95\%, CI=0.6635 - 5.0547) of plant leaf extract (Fig. 8).

Pearson's bivariate correlation analysis showed significant $(\mathrm{p}<0.0001)$ negative relationship between serum level of fluoride and testosterone of test rats after 20 ( $r=-0.780$; Fig. $9 \mathrm{a}$ ) and 40 days ( $\mathrm{r}=-0.862$; Fig. $9 \mathrm{~b}$ ) of fluoride treatment.

Testis

The level of intratesticular testosterone in experimental rats showed a significant $(\mathrm{p}<0.0001)$ decrease after $20(\mathrm{~F}=128.758)$ and 40 days $(\mathrm{F}=195.441)$ of fluoride treatment. The percentage decline was much higher (74.87\%) in group treated with 300 ppm NaF (Fig. 10).

Bonferroni multiple comparison test after ANOVA revealed a significant $(\mathrm{p}<0.0001)$ decrease in the intratesticular testosterone level after $20(95 \%, \mathrm{CI}=2.8300-4.6849)$ and 40 days $(95 \%, \mathrm{Cl}=5.7126-5.6302)$ of fluoride exposure between and within all groups studied.

Dunnett's t (2-sided) multiple comparison test illustrated a significant increase in intratesticular testosterone level in all fluoridated rats post-treated with $250(95 \%, \mathrm{Cl}=1.3256-6.1637, \mathrm{p}<0.01)$ and $500 \mathrm{mg} / \mathrm{kgbw} /$ day $(95 \%, \mathrm{Cl}=3.7171-8.7114, \mathrm{p}<0.0001)$ of plant leaf extract (Fig. 11).

Pearson's bivariate correlation analysis showed significant $(\mathrm{p}<0.0001)$ negative relationship between serum fluoride and intratesticular testosterone level in test rats after $20(\mathrm{r}=-0.915$; Fig. 12a) and 40 days ( $\mathrm{r}=-0.938$; Fig. 12b) of fluoride treatment.

\section{DISCUSSION}

The neuroendocrine system of the hypothalamus-pituitary-gonadal axis regulates reproduction in vertebrates and can be influenced by toxins and therefore affects the reproductive system. The activity of the hypothalamic-pituitary- gonadal axis is controlled by $\mathrm{GnRH}$ [6]. GnRH is a hypothalamic neuronal secretory decapeptide that plays a pivotal role in mammalian reproduction [7].

During the present study, data revealed elevated levels of FSH and LH, associated with significantly reduced serum testosterone level in rats exposed to fluoride, indicating inhibition of androgen synthesis in fluoridated rats. There was a significant increase in the serum level of FSH $(p<0.01)$ and LH $(p<0.0001)$ as compared to control group, but the disruption in the level of these hormones was more in rats after 40 days of fluoride intoxication. The serum level of these hormones in the groups that were given $B$. diffusa leaf extract in association with fluoride was demonstrated to be declined significantly for the level of FSH $(\mathrm{p}<0.05)$ as well as LH $(p<0.0001)$. The findings are in agreement with the study of Chen et al. [8] who explored the effects of high fluoride exposure on the reproductive function of 31 male adults in a high fluoride area with 26 subjects in normal area serving as a control group and revealed that

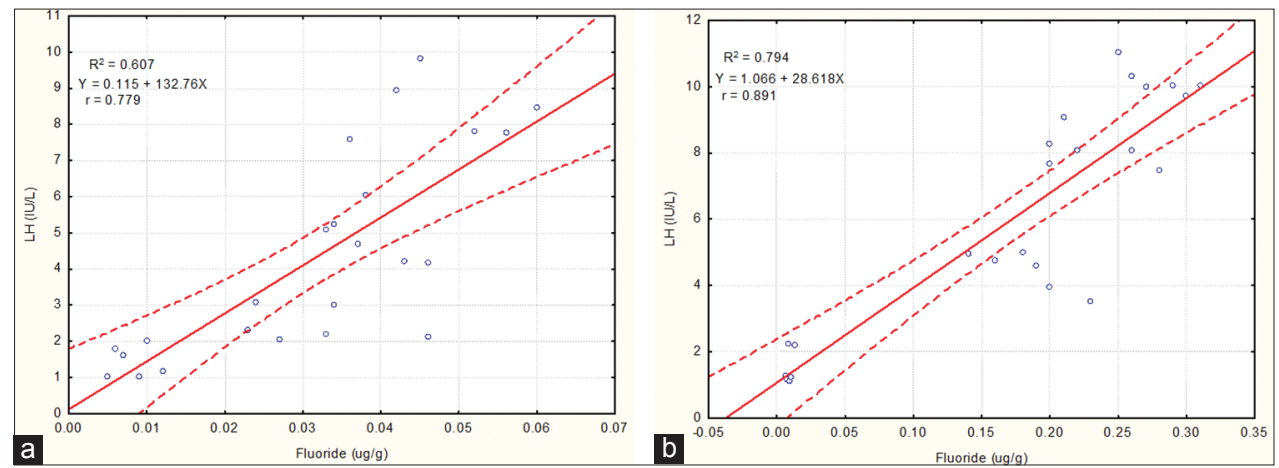

Fig. 6: Correlation and linear regression between serum fluoride level and luteinizing hormone after (a) 20 days, and (b) 40 days of fluoride intoxication 
the levels of serum LH and FSH were markedly increased $(p<0.001)$ among the subjects in the high fluoride area and that the serum level of testosterone was significantly decreased $(p<0.01)$ as compared to the control group. Reddy et al. [9] observed that exposure of rats to fluoride during early stages of development to a concentration of 4.5 and $9.0 \mathrm{ppm}$ administered in drinking water resulted in elevated levels of

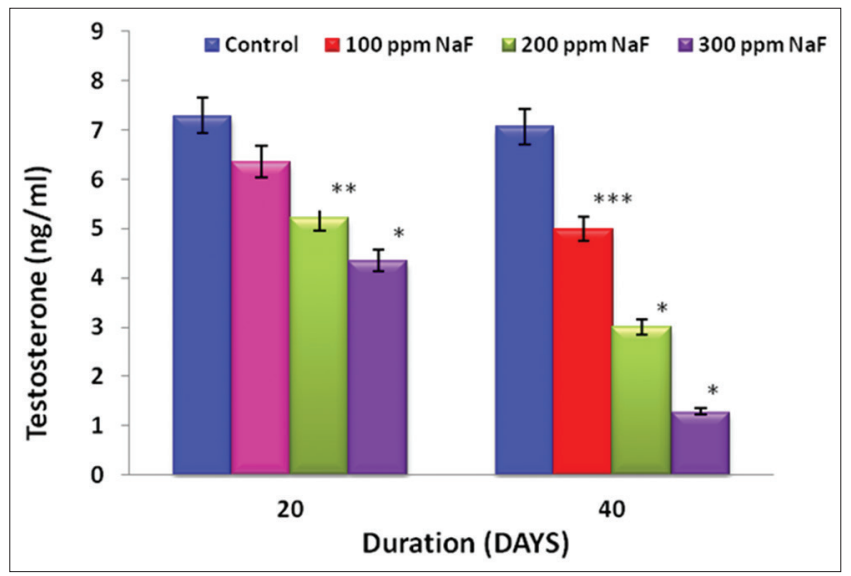

Fig. 7: Serum level of testosterone in control and (sodium fluoride) NaF-treated rats. Values are expressed as mean \pm SD. ${ }^{*} \mathbf{p}<0.0001, * * \mathrm{p}<0.001$ and ${ }^{* * *} \mathbf{p}<0.01$ NaF-treated groups compared with control

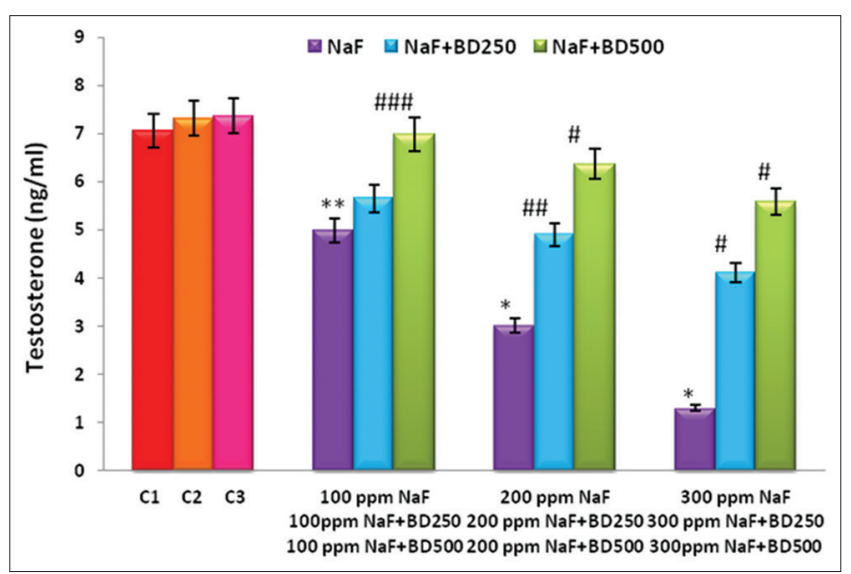

Fig. 8: Level of testosterone in serum of control (C1), positive control (C2 and C3), sodium fluoride (NaF)-treated, and combination of $\mathrm{NaF}$ and leaf extract-treated group. Values are represented as mean $\pm S D$. ${ }^{*} p<0.0001$ and $* * p<0.01$ compared with

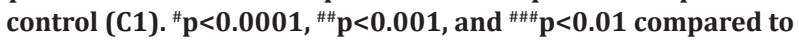
respective NaF-treated group
FSH and LH and significantly reduced serum testosterone levels in rats exposed to fluoride.

Fluoride-induced disruption of various hormones involved in male reproductive function was also studied in 75 fluorotic patients by Chauhan et al. $[10]$ and found significant $(\mathrm{p}<0.05)$ increase in serum FSH and prolactin and decreased LH and testosterone levels as per the severity of disease. Zhou et al. [11] also reported significantly ( $<<0.05)$ lower serum levels of FSH in male from defluoridation villages than that of high fluoride villages and control villages.

The FSH and LH are dimeric proteins which are secreted by anterior pituitary gonadotropes. It acts on the gonad in sequential and synergistic manner for the initiation of sexual maturation [12]. The main indicator of dysfunctioning of spermatogenesis is alteration of $\mathrm{FSH}, \mathrm{LH}$, and testosterone. For spermatogenesis initiation and spermatozoa maturation, FSH is necessary. It is reported that elevated levels of serum FSH indicate impairment of spermatogenesis and reflect the germ cell loss or damage to Sertoli cell, thereby affecting the feedback regulation of FSH secretion [13].

The testosterone is an important androgen produced in the testis and is involved in the initiation of spermatogenesis [14]. Many studies have reported the male reproductive defects induced by fluoride, such as the deleterious effects of $\mathrm{NaF}$ on testosterone level, spermatogenesis, sperm motility and morphology, and fertilizing ability $[1,15,16]$.

In the present study, it was found that there was a significant decrease in serum $(\mathrm{p}<0.01)$ and testis $(\mathrm{p}<0.0001)$ testosterone level after the treatment of rats with $\mathrm{NaF}$ as compared to control. Decrease was more prominent after 40 days of fluoride intoxication as compared to 20 days. With the supplementation of leaf extract, there was a significant $(p<0.01)$ increase in the serum and testicular level of testosterone.

Testosterone synthesis and production is the result of a series of complex biochemical interactions involving the hypothalamus, pituitary, and the testis. In the present study, the serum testosterone levels were decreased significantly $(\mathrm{p}<0.0001)$ as the concentration of fluoride was increased. Decreased serum testosterone levels have also been reported in human population exposed to fluoride at doses of 3-27 mg/day compared with a group of individuals exposed to fluoride at low doses of $2-13 \mathrm{mg} /$ day [17]. The decrease in serum testosterone observed in the present study could also be due to fluoride-induced damage of Leydig cells [18]

The present observations are supportive of previous findings in which significant $(\mathrm{p}<0.05)$ decline in the serum level of testosterone in men of fluoride polluted areas as compared to control [19]. Dong et al. [20] also reported decreased concentration of serum testosterone in guinea pigs. The decline in level of testosterone was $23.67 \%$ compared with control group. When male mice were treated with $0,25,50,100 \mathrm{mg} / \mathrm{L}$ of $\mathrm{NaF}$ in drinking water for 11 weeks, respectively, compared with the control group, Cao et al. [21] observed a significant increase in fluoride content and injury to the structure of testes. The testosterone contents
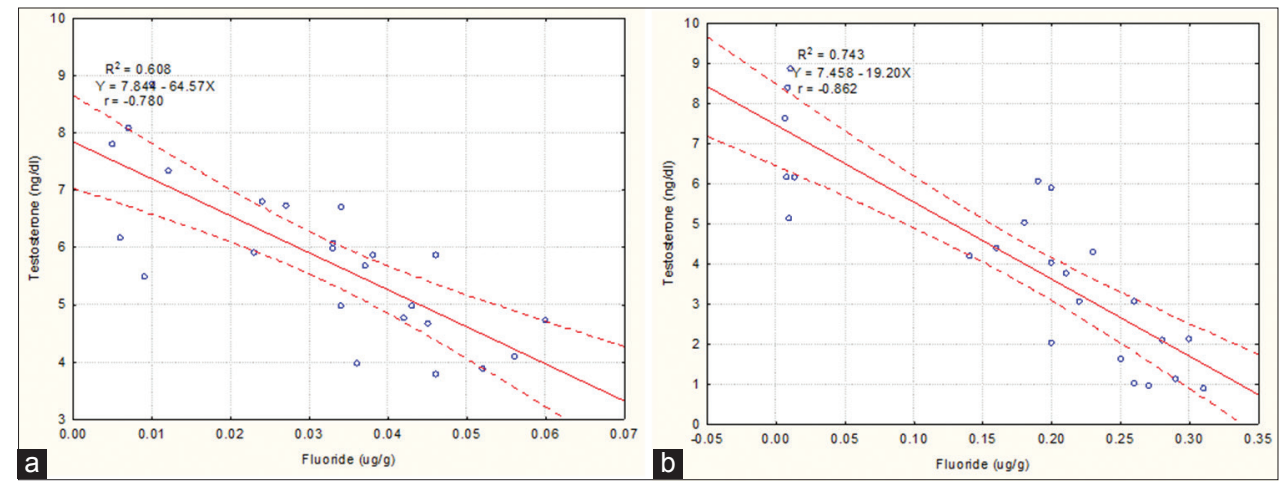

Fig. 9: Correlation and linear regression between level of serum fluoride and testosterone after (a) 20 days, and (b) 40 days of fluoride intoxication 
in serum and testis were lower than that of control group. The serum testosterone decreased by $61.22 \%$ in $100 \mathrm{mg} / \mathrm{L} \mathrm{NaF}$ groups, and the testis testosterone was remarkedly reduced by $44.72 \%$ and $43.95 \%$ in 50 and $100 \mathrm{mg} / \mathrm{L} \mathrm{NaF}$ groups. A similar decrease in serum and testis testosterone level on fluoride exposure has also been observed by Narayana and Chinoy [22] and Gupta et al. [23]

Fluoride interferes with spermatogenesis by modifying important cell signal transducers called G-protein-coupled receptors [24] which

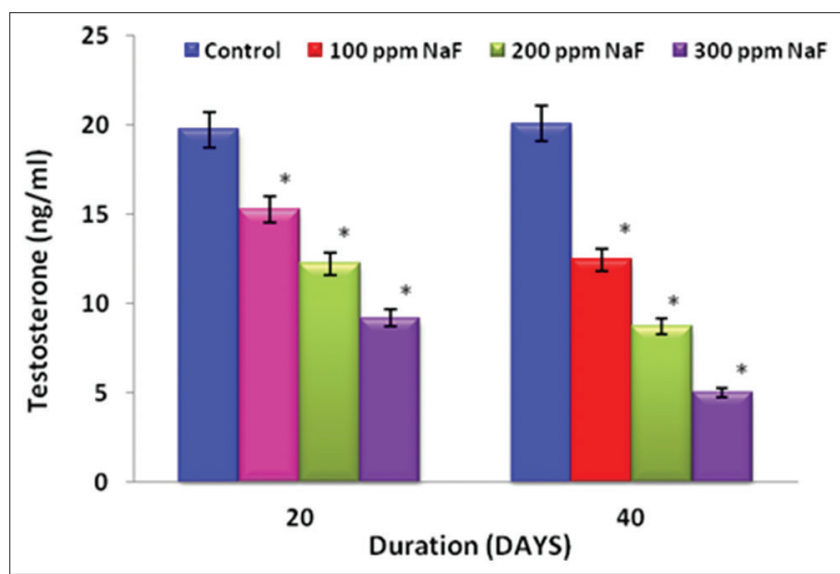

Fig. 10: Level of intratesticular testosterone of control and sodium fluoride (NaF)-treated rats. Values are expressed as mean \pm SD.

${ }^{*} \mathbf{p}<0.0001$ NaF-treated groups compared with control are used by the pituitary neurohormone-luteinizing hormone [25]. $\mathrm{LH}$ is an important regulator of testosterone production in Leydig cells. Therefore, F-induced modification of G-proteins could inhibit the release of testosterone, and since testosterone is essential for the initiation of spermatogenesis, this inhibition would eventually lead to low levels of testosterone, thereby impairing spermatogenesis $[15,26]$. It is reported that fluoride is known to accumulate in the pineal gland [27] and to inhibit the release of melatonin by the pineal gland [28]. Since melatonin has an anti-gonadotropic effect, it is conceivable that fluoride inhibition of melatonin indirectly but significantly increases the level of gonadotropins [29]. Under normal circumstances, elevated levels of gonadotropic hormones would result in increased testosterone levels. If there is an inability to increase testosterone due to fluoride interference, elevated gonadotropic hormones may be sustained, without eliciting a compensatory elevation of testosterone [1].

The present study demonstrates that excess fluoride exposure can induce endocrine hormone disruption over the hypothalamic-pituitarytestis axis by influencing the regulation of reproductive hormones, hence causing deleterious effects on spermatogenesis and alters sperm and semen quality. Furthermore, the results suggest that the leaf extract of $B$. diffusa is effective in alleviating the toxic effects of $\mathrm{NaF}$ on male reproductive hormones.

\section{ACKNOWLEDGMENT}

The financial assistance in the form of Innovation in Science Pursuit for Inspired Research grant by the Department of Science and Technology, Government of India, is gratefully acknowledged.

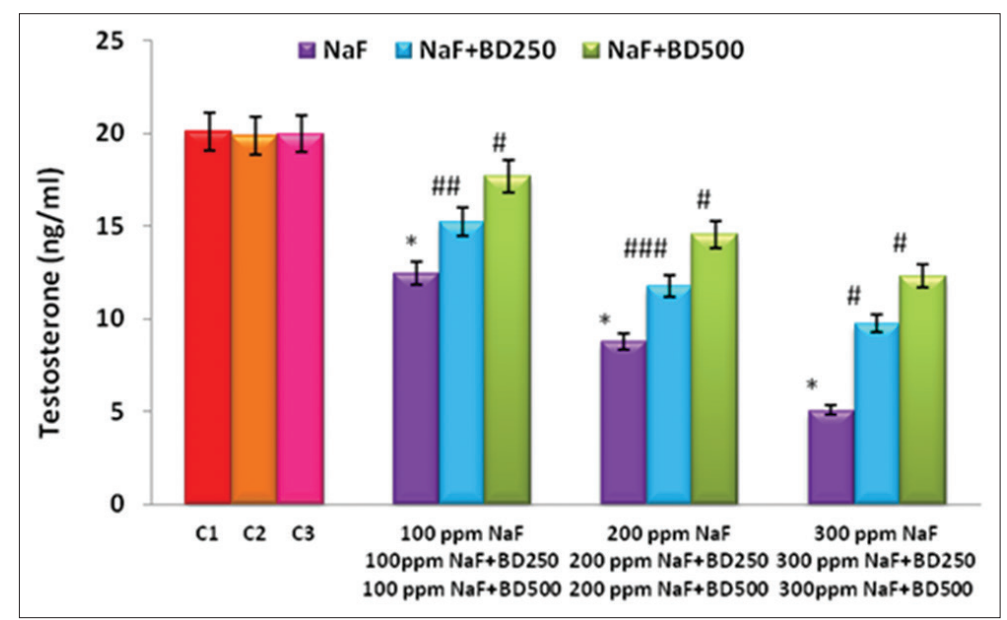

Fig. 11: Level of intratesticular testosterone in control (C1), positive control (C2 and C3), sodium fluoride (NaF)-treated, and combination of $\mathrm{NaF}$ and leaf extract-treated group. Values are represented as mean \pm SD. ${ }^{*} \mathbf{p}<0.0001$ compared with control $(\mathrm{C1})$. ${ }^{\#} \mathbf{p}<0.0001,{ }^{\#} \mathbf{p}<0.001$, and ${ }^{\# \#} \mathbf{p}<0.01$ compared to respective NaF-treated group
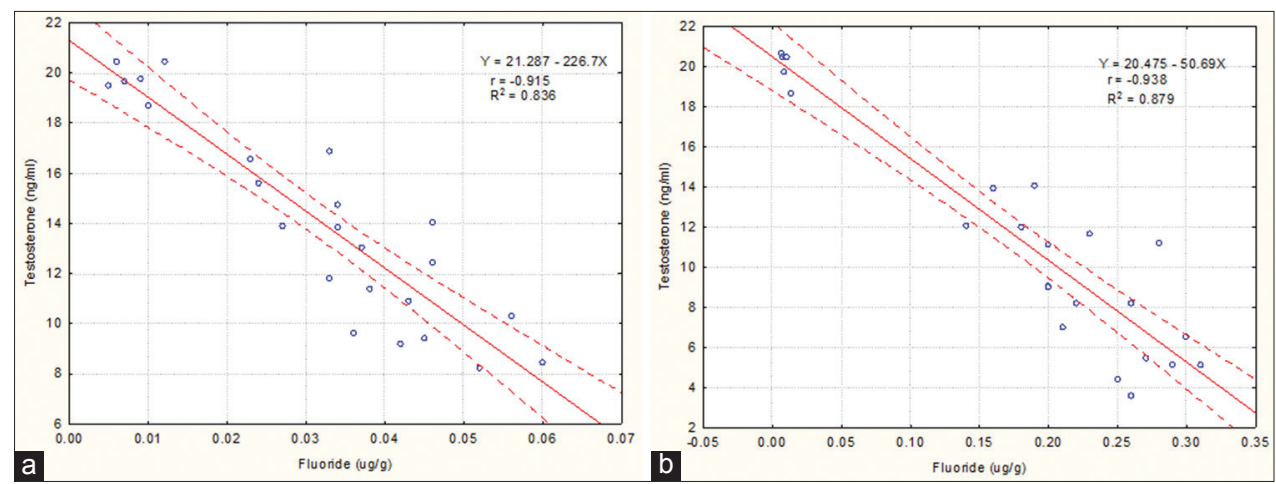

Fig. 12: Correlation and linear regression between level of testicular fluoride and testosterone after (a) 20 days, and (b) 40 days of fluoride intoxication 


\section{REFERENCES}

1. Long H, Jin Y, Lin M, Sun Y, Zhang L, Clinch C. Fluoride toxicity in the male reproductive system. Fluoride 2009;42(4):260-76.

2. Chimento A, Sirianni R, Casaburi I, Pezzi V. Role of estrogen receptors and $g$ protein-coupled estrogen receptor in regulation of hypothalamuspituitary-testis axis and spermatogenesis. Front Endocrinol (Lausanne) 2014;5:1.

3. Maruska KP, Fernald RD. Social regulation of gene expression in the hypothalamic-pituitary-gonadal axis. Physiology (Bethesda) 2011;26(6):412-3

4. Ma X, Cheng X, Li F, Guo J. Experimental research on endocrine disturbing effect of fluorin on hypothalamus-hypophysis-testis axis in male rats. Wei Sheng Yan Jiu 2008;37(6):733-5.

5. Narendhirakannan RT, Subramanian S, Kandaswamy M. Biochemical evaluation of antidiabetogenic properties of some commonly used Indian plants on streptozotocin-induced diabetes in experimental rats. Clin Exp Pharmacol Physiol 2006;33(12):1150-7.

6. Filicori M, Crowley WF Jr. The study of GnRH control of reproductive function. Ups J Med Sci 1984;89(1):13-8.

7. Ramakrishnappa N, Rajamahendran R, Lin YM, Leung PC. GnRH in non-hypothalamic reproductive tissues. Anim Reprod Sci 2005;88(1-2):95-113.

8. Chen P, Meng X, He J, Yun Z, Qin Y, Ge X, et al. Effects of high fluoride on reproductive endocrine of male adults. Endem Dis Bull 1997;12(2):57-8.

9. Reddy PS, Pushpalatha T, Reddy PS. Suppression of male reproduction in rats after exposure to sodium fluoride during early stages of development. Naturwissenschaften 2007;94(7):607-11.

10. Chauhan DS, Singh VK, Mishra S, Tripathi S, Tiwari M, Tomar A. Influence of fluoride exposure on hypothalamic pituitary gonadal axis hormones and semen quality. Asian J Biol Life Sci 2013;3:201-6.

11. Zhou T, Duan L, Ding Z, Yang R, Li S, Xi Y, et al. Environmental fluoride exposure and reproductive hormones in male living in endemic fluorosis villages in China. Life Sci J 2012;9:1-7.

12. Crawford JL, Heath DA, Haydon LJ, Thomson BP, Eckery DC. Gene expression and secretion of $\mathrm{LH}$ and FSH in relation to gene expression of $\mathrm{GnRH}$ receptors in the brushtail possum (Trichosurus vulpecula) demonstrates highly conserved mechanisms. Reproduction 2009;137(1):129-40.

13. Bergmann M, Behre HM, Nieschlag E. Serum FSH and testicular morphology in male infertility. Clin Endocrinol (Oxf) 1994;40(1):133-6.

14. Pushpalatha T, Srinivas M, Sreenivasula Reddy P. Exposure to high fluoride concentration in drinking water will affect spermatogenesis and steroidogenesis in male albino rats. Biometals 2005;18(3):207-12.

15. Zhang JH, Liang C, Ma JJ, Niu RY, Wang JD. Effects of sodium fluoride and sulfur dioxide on sperm motility and serum testosterone in male rats. Fluoride 2006;39(2):126-31

16. Sun Z, Niu R, Wang B, Wang J. Altered sperm chromatin structure in mice exposed to sodium fluoride through drinking water. Environ Toxicol 2014;29(6):690-6.

17. Ortiz-Pérez D, Rodríguez-Martínez M, Martínez F, Borja-Aburto VH, Castelo J, Grimaldo JI, et al. Fluoride-induced disruption of reproductive hormones in men. Environ Res 2003;93(1):20-30.

18. Susheela AK, Jethanandani P. Circulating testosterone levels in skeletal fluorosis patients. J Toxicol Clin Toxicol 1996;34(2):183-9.

19. Hao P, Ma X, Cheng X, Ba Y, Zhu J, Cui L. Effect of fluoride on human hypothalamus-hypophysis-testis axis hormones. Wei Sheng Yan Jiu 2010;39(1):53-5.

20. Dong C, Cao J, Cao C, Han Y, Wu S, Wang S, et al. Effects of fluoride and aluminum on expressions of StAR and P450scc of related steroidogenesis in guinea pigs' testis. Chemosphere 2016;147:345-51.

21. Cao J, Chen Y, Chen J, Yan H, Li M, Wang J. Fluoride exposure changed the structure and the expressions of $\mathrm{Y}$ chromosome related genes in testes of mice. Chemosphere 2016;161:292-9.

22. Narayana MV, Chinoy NJ. Effect of fluoride on rat testicular steroidogenesis. Fluoride 1994;27:7-12.

23. Gupta RS, Khan TI, Agrawal D, Kachhawa JB. The toxic effects of sodium fluoride on the reproductive system of male rats. Toxicol Ind Health 2007;23(9):507-13.

24. Chabre M. Aluminofluoride and beryllofluoride complexes: A new phosphate analogs in enzymology. Trends Biochem Sci 1990;15(1):6-10.

25. Payne AH, O'Shaughnessy PJ. Structure, function and regulation of steroidogenic enzymes in the Leydig cell. In: Payne AH, Hardy MP, Ruccell LD, editors. The Leydig Cell. Vienna: Cache River Press; 1996. p. $259-85$.

26. Sharma B, Sharma P, Joshi SC. Mitigating effects of Zingiber officinale against reproductive toxicity induced by dicholovos in male rats. Int $\mathrm{J}$ Pharm Pharm Sci 2017;9(5):107-3.

27. Luke J. Fluoride deposition in the aged human pineal gland. Caries Res 2001;35(2):125-8

28. Silman RE, Leone RM, Hooper RJ, Preece MA. Melatonin, the pineal gland and human puberty. Nature 1979;282(5739):301-3.

29. Tokar' VI, Savchenko ON. Effect of inorganic fluorine compounds on the functional state of the pituitary-testis system. Probl Endokrinol (Mosk) 1977;23(4):104-7. 